\title{
Sediment Denitrification in Two Contrasting Tropical Shallow Lagoons
}

\author{
Alex Enrich Prast, Ana Lucia Santoro, Rodrigo S. Coutinho, Lars Peter Nielsen and \\ Francisco A. Esteves
}

\section{Linköping University Post Print}

\section{Tweet}

N.B.: When citing this work, cite the original article.

The original publication is available at www.springerlink.com:

Alex Enrich Prast, Ana Lucia Santoro, Rodrigo S. Coutinho, Lars Peter Nielsen and Francisco A. Esteves, Sediment Denitrification in Two Contrasting Tropical Shallow Lagoons, 2016, Estuaries and Coasts, (39), 3, 657-663.

http://dx.doi.org/10.1007/s12237-015-0017-5

Copyright: Springer Verlag (Germany)

http://www.springerlink.com/?MUD=MP

Postprint available at: Linköping University Electronic Press

http://urn.kb.se/resolve?urn=urn:nbn:se:liu:diva-127546 


\title{
Sediment denitrification in two contrasting tropical shallow lagoons
}

\author{
Running head: Denitrification in tropical lagoons
}

\author{
Alex Enrich-Prast ${ }^{1,2}$, Ana L. Santoro1 ${ }^{1}$, Rodrigo S. Coutinho ${ }^{3}$, Lars Peter Nielsen ${ }^{4}$, \\ Francisco A. Esteves ${ }^{3,5}$
}

\begin{abstract}
${ }^{1}$ Laboratório de Biogeoquímica, Universidade Federal do Rio de Janeiro (UFRJ), Rio de Janeiro (RJ), 21941-971, Brazil.

${ }^{2}$ Department of Environmental Change, Linköping University, 581 83, Linköping, Sweden

${ }^{3}$ Laboratório de Limnologia, Universidade Federal do Rio de Janeiro (UFRJ), Rio de Janeiro (RJ), 21941-971, Brazil

${ }^{4}$ Department of Biology, University of Aarhus. Ny Munkegade 114, DK8000 Aarhus C, Denmark.

${ }^{5}$ Núcleo de Pesquisas em Ecologia e Desenvolvimento Sócio-ambiental de Macaé - NUPEM, Universidade Federal do Rio de Janeiro - UFRJ, Av. Rotary Club, s/n, São José do Barreto, CEP 28970000, Macaé, RJ, Brazil
\end{abstract}

*e-mail: aeprast@biologia.ufrj.br

Keywords: nitrogen, denitrification, oxygen consumption, sediment, tropical, coastal lagoons.

\begin{abstract}
Sediment denitrification was monthly evaluated in two tropical coastal lagoon with different trophic states using the ${ }^{15} \mathrm{~N}$ isotope pairing technique. Denitrification rates were very low in both environments, always $<5.0 \mu \mathrm{mol} \mathrm{N} \mathrm{N}^{-2} \mathrm{~h}^{-1}$ and were not significantly different between them. Oxygen consumption varied from 426 to $4248 \mu \mathrm{mol} \mathrm{O}_{2} \mathrm{~m}^{-2} \mathrm{~h}^{-1}$ and was generally 3 times higher in the meso-eutrophic than the oligotrophic lagoon. The low denitrification activity was ascribed to both low water $\mathrm{NO}_{3}{ }^{-}$concentrations $(<2.0 \mu \mathrm{M})$ and little nitrate supply from nitrification. There was no correlation of denitrification with nitrate or ammonium fluxes. Sediments in temperate environments with similar oxygen consumption rates usually presented a higher proportion of nitrification-denitrification rates. Sediment oxygen consumption was a good predictor of sediment denitrification in both studied lagoons.
\end{abstract}




\section{INTRODUCTION}

Denitrification is a dissimilatory nitrate reduction process in that nitrate or nitrite $\left(\mathrm{NO}_{3}{ }^{-}\right.$or $\left.\mathrm{NO}_{2}^{-}\right)$is reduced anaerobically to $\mathrm{N}_{2}$ by heterotrophic facultative anaerobic bacteria. Denitrification requires an anoxic environment and a source of both organic matter and nitrate (Mosier et al., 2002; Morley et al., 2010). As available fixed nitrogen in sediments is mostly in the form of ammonium $\left(\mathrm{NH}_{4}{ }^{+}\right)$, sediment denitrification depends on local rates of nitrification (Newcomer et al., 2012) unless there is a flux of nitrate into the sediment from the overlying bottom waters.

Nitrate produced in the aerobic zone (or nitrate from the overlying water) diffuses into the suboxic zone where denitrification occurs (Nielsen et al., 1990; RisgaardPetersen, 2003). This process combination is commonly referred to as coupled nitrification-denitrification, while denitrification supported by the physical influx of nitrate is referred to as direct denitrification (An and Joye, 2001; Fennel, et al., 2009). According to Fennel et al. (2009), sediment oxygen consumption (SOC) should be an effective predictor of sediment denitrification. The depth of the aerobic zone in aquatic sediments is directly affected by SOC, which is associated with organic matter decomposition and nitrification (Seitzinger, et al., 2006; Small, et al., 2014).

Coastal aquatic environments are among aquatic systems with the highest degree of eutrophication, derived from increased nutrient inputs (Vidal et al., 1999) and these environments present some of the highest reported denitrification values (Herbert, 1999). Boesch (2002) reported that $67 \%$ of the combined surface area of US estuaries exhibited moderate to high degrees of eutrophication and similar results have emerged in Europe and other continents (Duarte et al., 2009). 
Freshwater systems are assumed to account for approximately $20 \%$ of the total global denitrification (Seitzinger et al. 2006) because sediment denitrification is the major pathway of fixed $\mathrm{N}$ loss from natural and human-altered aquatic systems. However, Burgin \& Hamilton (2007) question if the relative role of denitrification as a removal pathway has been overestimated over the years. It has to be noted that denitrification in lake sediments has been widely studied in temperate and boreal environments, but studies in tropical lake sediments are scarce and very little data is available (Pina-Ochoa and Alvarez-Cobelas, 2006; Solomon, et al., 2009). This is even more evident for denitrification measurements in coastal lagoons

The aim of this study was to evaluate the relative importance of denitrification rates and its relation with oxygen consumption and other regulatory factors in two contrasting tropical shallow lagoons with different trophic states.

\section{STUDY AREA}

Imboassica $\left(22^{\circ} 25^{\prime} \mathrm{S}\right.$ e $\left.42^{\circ} 56^{\prime} \mathrm{W}\right)$ and Cabiúnas Lagoons $\left(22^{\circ} 00^{\prime} \mathrm{S}\right.$ e $42^{\circ} 00^{\prime}$ W) are situated in the north coast of Rio de Janeiro state (southeast of Brazil, Fig. 1). This area has minimum and maximum monthly mean temperatures ranging from 20.7 ${ }^{\circ} \mathrm{C}$ in July to $26.2{ }^{\circ} \mathrm{C}$ in February, respectively (Inmet, 1992). Both Imboassica and Cabiúnas Lagoons are elongated perpendicularly to the coastline, are shallow and relatively close to each other (30 km), and have a similar watershed size (50 and 45 $\mathrm{Km}^{2}$, respectively).

Imboassica Lagoon, with an area of $3.26 \mathrm{Km}^{2}$, is located in a Quaternary FluvioMarine Plain where the tropical forest was logged (Cprm, 2000). The predominant land use in the watershed of this lake is extensive pasture, but the lake receives important nutrient inputs from urban sources. Sewage discharges contributed to eutrophication of 
Imboassica Lagoon mainly after 1995 (Esteves, 1998). Imboassica was classified as mesotrophic to eutrophic during the study period (Salas \& Martino, 2001). Cabiúnas Lake is smaller $\left(0.34 \mathrm{Km}^{2}\right)$ and less impacted by human activities because it is located within a conservation area (Restinga de Jurubatiba National Park). This ecosystem is located in a Quaternary Marine Sandy Plain where the original terrestrial vegetation (named Restinga) is preserved (Cprm, 2000). Cabiunas was classified as oligotrophic during the study period (Salas \& Martino 2001). Some limnological characteristics for Imboassica and Cabiunas lagoons during the studied period are presented in Table 1. Both lagoons present carbonate sediments with some level of bioirrigation. They present submerged aquatic macrophytes, but only in the margins. More information about both lagoons can be find at Marotta et al. (2010).

\section{MATERIALS AND METHODS}

Denitrification, Sediment Oxygen Consumption (SOC) and nitrate and ammonium fluxes were measured monthly from February to October 2001 according to Dalsgaard et al. (2000). During each month, water (van D’orn bottle) and big sediment cores (Kajak core sampler) were collected from the central region of each lagoon, without the presence of submerged macrophytes. Smaller sediment cores (Plexiglas cores, $15.8 \times 3.6 \mathrm{~cm}$ )were carefully subsampled from the big cores in the field and immediately transported to the field laboratory.

In the field lab, the small cores were fixed in two big containers (ca. 50L), one for each lagoon, with a stirring system specially designed to start-end incubations. In each lagoon, we incubated eight cores with stirring systems (5 with sediment and water and 3 only with water). In each container, the cores were completely covered with lagoon water, that was kept circulating with aquarium pumps to maintain oxygen 
concentration at saturation level. All cores were kept under these aerated conditions at lagoon in situ temperature during 2 to 4 hours for stabilization. Temperature in the cores did not changed more than $2^{\circ} \mathrm{C}$ during the whole stabilization and incubation period. All incubations were performed in the dark. Sediment oxygen consumption was used as a proxy of site aerobic mineralization (Dalsgaard et al, 2000).

The sediment fluxes of nitrate and ammonium and oxygen were determined with a total incubation from 1 to 2 hours at Imboassica and 2 to 4 hours at Cabiunas lagoons.s. Oxygen consumption was only measured when oxygen final concentration was never lower than $80 \%$ saturation (Dalsgaard et al, 2000). After measuring the nitrate, ammonium and oxygen fluxes, the cores were kept open under the water inside the big containers for another period of stabilization of 3 hours before addition of ${ }^{15} \mathrm{NO}_{3}{ }^{-}$, indicating the beginning of denitrification incubation. Denitrification rates were obtained through the isotopic paring technique (IPT) proposed by Nielsen (1992) and after addition of $1 \mathrm{ml}^{15} \mathrm{NO}_{3}{ }^{-}$(5 mM) to each sediment core yielding a concentration of approximately $100 \mu \mathrm{M}$ in the water column. This relatively high concentration of added ${ }^{15} \mathrm{NO}_{3}{ }^{-}$, allows the determination of very low denitrification rates, because the mass spectrometer is sensitive enough to measure small increases of ${ }^{29} \mathrm{~N}_{2}$ concentrations. In this study, the detection limit was $0.01 \mu \mathrm{mol} \mathrm{N} \mathrm{m}^{-2} \mathrm{~h}^{-1}$.

We waited a period of 5 to 10 minutes for ${ }^{15} \mathrm{NO}_{3}{ }^{-}$equilibration. After the incubation of 1 to 2 and 2 to 4, respectively in Imboassica and Cabiunas lagoons, we ended the denitrification incubation by adding some drops of $\mathrm{ZnCl}_{2}(1 \mathrm{mM})$ and mixing the sediment and the water in the core. After one minute, we sample $20 \mathrm{ml}$ of the slurry and transferred to $12 \mathrm{ml}$ exetainers with $100 \mu \mathrm{l} \mathrm{ZnCl}_{2}(1 \mathrm{mM})$ for preservation. Within a week, $3 \mathrm{ml}$ of the water inside the exetainers were replaced with He and the exetainers were kept at $4^{\circ} \mathrm{C}$ until analysis at the University of Aarhus (Denmark). 
Assuming random mixture of the added ${ }^{15} \mathrm{NO}_{3}{ }^{-}$with ${ }^{14} \mathrm{NO}_{3}{ }^{-}$in the water and produced in the sediment by nitrification, the formation of ${ }^{29} \mathrm{~N}_{2}\left({ }^{14} \mathrm{~N}^{15} \mathrm{~N}\right)$ and ${ }^{30} \mathrm{~N}_{2}$ $\left({ }^{15} \mathrm{~N}^{15} \mathrm{~N}\right)$ by the end of the incubation were used to calculate actual denitrification rates and Dn (coupled nitrification-denitrification) and Dw (denitrification from nitrate from the water column) fractions (Nielsen, 1992). because the mass spectrometer can measure as long the lower measurements performed at this study.

Oxygen, temperature and salinity concentrations were measured in the field and in the laboratory with an oxymeter (YSI-55). Nitrate, nitrite, phosphate and chlorophyll-a were measured according to Golterman, et al., (1978) and ammonium according to Bower and Holmhansen (1980). Nitrogen isotope species were analyzed in a mass spectrometer (Europa Scientific) at the University of Aarhus (Denmark).

The sediment oxygen consumption values from both lagoons presented a Gaussian distribution (normality test, $\mathrm{p}<0.05$ ) and were compared using the unpaired ttest at the $5 \%$ level. The denitrification rates and nitrate and ammonium fluxes presented no Gaussian distribution (normality test, $\mathrm{p}<0.05$ ). We compared the denitrification rates with the Mann-Whitney test $(\mathrm{p}<0.05)$. The Dn and Dw fractions were compared through the nonparametric Kruskal-Wallis test followed by Dunn's post test, which were both evaluated at the $5 \%$ level.

\section{RESULTS}

The denitrification rates were very low in both environments and never reached values higher than $5.0 \mu \mathrm{mol} \mathrm{N} \mathrm{N}^{-2} \mathrm{~h}^{-1}$. Imboassica and Cabiunas denitrification rates varied from 0.21 to $1.7 \mu \mathrm{mol} \mathrm{N} \mathrm{m}^{-2} \mathrm{~h}^{-1}$ and 0.01 to $4.3 \mu \mathrm{mol} \mathrm{N} \mathrm{N}_{2} \mathrm{~m}^{-2} \mathrm{~h}^{-1}$ (Fig. $2 \mathrm{~A}$ and B), respectively. The denitrification rates were slightly higher in Cabiúnas Lagoon in 
the first three months of the study, but as a whole, there was not a significant difference (Mann-Whitney, $\mathrm{p}<0.05$ ) between the lagoons.

Sediment oxygen consumption was significantly higher in Imboassica than in Cabiunas Lagoon (t-test, $\mathrm{p}<0.05)$. Imboassica and Cabiunas SOC rates varied from 1,838 to $4,248 \mu \mathrm{mol} \mathrm{O} 2 \mathrm{~m}^{-2} \mathrm{~h}^{-1}$ and from 426 to $1,294 \mu \mathrm{mol} \mathrm{O} \mathrm{m}^{-2} \mathrm{~h}^{-1}$ (Fig. $2 \mathrm{C}$ and D), respectively.

Ammonium and nitrate fluxes were very variable in Imboassica and Cabiunas lagoons being more intense and with higher fluxes at the first one. $\mathrm{NH}_{4}{ }^{+}$fluxes varied from a release of 1,212.9 $\mu_{\mathrm{mol} \mathrm{NH}}{ }^{+} \mathrm{m}^{-2} \mathrm{~h}^{-1}$ in March 2001 to an assimilation of 347.5 $\mu \mathrm{mol} \mathrm{NH}{ }_{4}^{+} \mathrm{m}^{-2} \mathrm{~h}^{-1}$ in May 2001 in Imboassica and from a release of $54.3 \mu \mathrm{mol} \mathrm{NH}_{4}{ }^{+} \mathrm{m}^{-}$ ${ }^{2} \mathrm{~h}^{-1}$ in March 2001 to assimilation of $51.7 \mu \mathrm{mol} \mathrm{NH}{ }^{+} \mathrm{m}^{-2} \mathrm{~h}^{-1}$ in August 2001 in Cabiúnas lagoon (Figure $2 \mathrm{E}$ and $\mathrm{F}$ ). $\mathrm{NO}_{3}{ }^{-}$fluxes also varied from sediment release to assimilation in both lagoons, but this variation was in a lower range than the $\mathrm{NH}_{4}{ }^{+}$ fluxes (Figure $2 \mathrm{G}$ and $\mathrm{H}$ ). There was not a clear pattern of assimilation or release of $\mathrm{NH}_{4}{ }^{+}$and $\mathrm{NO}_{3}{ }^{-}$, neither a correlation of these fluxes with denitrification or SOC rates. The relative dominance of the Dn over the Dw fraction was observed in both lagoons (Fig. 2 A and B). Both environments presented a significant relationship (F test, $\mathrm{p}<$ 0.05) between coupled nitrification-denitrification rates (Dn) and SOC (Fig. 3). However, the slope of this relationship and the $R$ value were higher in Cabiúnas than in Imboassica Lagoon.

The water nitrate concentrations were below $2.0 \mu \mathrm{M}$ at all sampling months in both lagoons. Ammonium concentrations were also lower than $2.0 \mu \mathrm{M}$ during all sampling months in Cabiúnas lagoon. However, ammonium concentrations varied from $<2.0 \mu \mathrm{M}$ to $46.8 \mu \mathrm{M}$ in Imboassica Lagoon. Although solar radiation did reached the 
bottom of the studied lagoons, there was no colonization of microalgae over the sediment.

\section{DISCUSSION}

The present study shows rates of sediment denitrification and water nitrate concentrations up to two orders of magnitude lower than the average estimated for coastal lagoons (Herbert, 1999; Piña-Ochoa \& Álvarez-Cobelas 2006; Fennel et al., 2009). The absence of a temporal variability over the studied months and between both lagoons were quite unexpected and different from the usually observed in the literature. The metabolism of both lagoons changes during the year (Marotta et al, 2010) and these changes apparently did not have any influence on the denitrification rates. The studied lagoons are quite different in terms of geological formation, some limnological characteristics (Table 1) and anthropogenic impacts (more details in Marotta et al, 2010). Even with all these differences, denitrification rates were very low and similar in both lagoons.

Previous experiments in these lagoons showed that all measurements performed with ${ }^{15} \mathrm{NO}_{3}{ }^{-}$addition above $15 \mu \mathrm{M}$ (final concentration) resulted in constant Dn values (data not shown) and we used $100 \mu \mathrm{M}{ }^{15} \mathrm{NO}_{3}{ }^{-}$in our incubations, so one of the assumptions of the IPT method was fulfilled (Nielsen, 1992). The same methodology was also used for measuring sediment denitrification rates in several lakes from the Amazon Region. The majority of the measured rates were also low, but in few environments they were one order of magnitude higher (manuscript in preparation). This is a strong indication that the isotope pairing technique method works in the 
studied lagoons and that the denitrification rates were accurately measured and represent real denitrification rates. Ferguson and Eyre (2007) suggested that the IPT method could underestimate denitrification rates up to 85\% Even assuming this level of underestimation and correcting the measured rates in our study, the majority of the measurements would still be below $5.0 \mu \mathrm{mol} \mathrm{N}_{2} \mathrm{~m}^{-2} \mathrm{~h}^{-1}$, a surprisingly low rate.

The low nitrate concentrations in the water column could be a reasonable explanation for the low denitrification rates reported in this study. Nitrate concentrations were always lower than $2.0 \mu \mathrm{M}$ at all sampling months, a much lower value than reported for environments with higher denitrification rates (Herbert, 1999). The total denitrification rates were low, but we observed an important contribution of coupled nitrification-denitrification in both the oligotrophic and the meso-eutrophic tropical lagoons.

Low or absent denitrification rates were previously reported in other tropical lagoon sediments (Biesboer, Esteves et al., 1998) and floodplain lake sediments in the Pantanal (Figueiredo Souza, et al., 2012) and clearwater Amazonian lakes (Kern, et al., 1996; Esteves, 1998; Esteves et al., 2001; Nielsen et al., 2004). Denitrification rates were also absent in periphytic communities associated with Amazonian aquatic macrophytes (Enrich-Prast \& Esteves, 1998, Enrich-Prast et al., 1999) and stream tropical sediments (Solomon et al., 2009).

SOC rates observed in Cabiunas Lagoon are comparable to rates of a temperate meso-eutrophic lake (Sweerts et al., 1991), while Imboassica Lagoon rates were higher than those observed at a temperate eutrophic shallow lagoon (Dedieu et al., 2007). These differences may be mainly attributed to higher temperatures in the tropics (Cardoso et al, 2014). The slope of the linear regression between Dn and SOC of the studied tropical environments $(<0.001)$ is much lower than temperate slopes (ca. 0.10: 
Seitzinger et al., 2006; Fennel et al., 2009 and 0.06: Piehler and Smyth, 2011). Not only the slope, but also denitrification rates are much lower than those observed by these temperate studies . Between the tropical environments, the slope of the meso-eutrophic studied lagoon (Imboassica) was one order of magnitude lower than the oligotrophic one (Cabiunas) (Fig. 3).

Sediment oxygen consumption rates regulate aerobic layer depth in sediments and consequently can regulate denitrification in different ways; directly, by creating anoxic conditions, or indirectly, by controlling the extent of nitrification (Jensen, et al., 1994; Nizzoli, et al., 2010, Piehler and Smyth, 2011).

The intense heterotrophic metabolism can eventually cause extinction in the sediment aerobic layer, limiting nitrification and maintaining very low nitrate concentrations. In tropical environments with low nitrate concentrations, high temperatures and intense SOC throughout the year, nitrification and coupled nitrification-denitrification can be continuously limited by oxygen limitation. .

SOC direct regulation of denitrification occurred in the sediment of Cabiunas and Imboassica lagoons. This system showed lower rates of SOC and this was the most correlated factor with denitrification (data not shown). However, denitrification in sediments containing high amounts of labile organic matter is often limited by the availability of nitrate or nitrite (Fennel, et al., 2009). The extremely high SOC of Imboassica Lagoon seems to indirectly regulate denitrification by shortening the nitrification activity, and nitrate availability was the main and most important regulation factor for denitrification.

Dedieu et al. (2007) observed a negative seasonal correlation between SOC and coupled nitrification-denitrification rates in surface sediments of a temperate eutrophic shallow lagoon. Piehler and Smyth (2011) found a strong correlation between SOC and 
denitrification rates in a range of temperate environments and habitats and suggested that SOC should be used to predict denitrification in environments with low nitrate availability. Our results somehow corroborate the conclusions from Piehler and Smyth. However, even though we also observed a significant correlation, every system presents its own correlation and a general correlation cannot be applied indiscriminately to predict denitrification.

\section{ACKNOWLEDGMENTS}

This research is a contribution to projects financed from several Brazilian research agencies (FAPERJ, CAPES and CNPq) and also from projects financed by Petrobras.

A. Enrich-Prast and FA Esteves are research fellows from CNPq. We thank the Coordinate Research Network - CRN3 - Nnet Project. Interamerican Institute for Global Change Research.

\section{LITERATURE}

AN, S.; JOYE, S. B. Enhancement of coupled nitrification-denitrification by benthic photosynthesis in shallow estuarine sediments. Limnology and Oceanography 46: 6274, 2001

BIESBOER, D. D.; ESTEVES, F. D.; ENRICH-PRAST, A. Nitrogen fixation and denitrification in Lagoa Imboacica, a coastal lagoon of Rio de Janeiro State, Brazil. In: WILLIAMS, W. D. e SLADECKOVA, A. (Ed.). International Association of Theoretical and Applied Limnology 26: 3-7, 1995

BOWER, C. E.; HOLMHANSEN, T. A Salicylate-Hypochlorite Method for Determining Ammonia in Seawater. Canadian Journal of Fisheries and Aquatic Sciences, 37: 794-798, 1980

CARDOSO, S., ENRICH-PRAST, A., PACE, M., ROLAND, F. Do organic carbon mineralization models extrapolate to warmer tropical sediments? Limnology and Oceanography 59: 48-54, 2014 
CHRISTENSEN, P. B. et al. Sediment mineralization, nutrient fluxes, denitrification and dissimilatory nitrate reduction to ammonium in an estuarine fjord with sea cage trout farms. Aquatic Microbial Ecology 21: 73-84, 2000

CPRM. Unidades morfoesculturais e geomorfológicas de Macaé. Rio de Janeiro: CPRM 2000.

DEDIEU, K. et al. Coupling of carbon, nitrogen and oxygen cycles in sediments from a Mediterranean lagoon: a seasonal perspective. Marine Ecology-Progress Series 346: 4559, 2007.

DUARTE, C. M., CONLEY, D. J., CARSTENSEN, J., SANCHEZ-CAMACHO, M. Return to Neverland: shifting baselines affect eutrophication restoration targets. Estuaries Coasts 32:29-36, 2009.

ESTEVES, F. A. Lagoas Costeiras: Origem, funcionamento e possibilidades de manejo. In: ESTEVES, F. A. (Ed.). Ecologia de Lagoas Costeiras. Macaé: NUPEM: 63-87, 1998

ESTEVES, F. A.; ENRICH-PRAST, A.; BIESBOER, D. D. Potential denitrification in submerged natural and impacted sediments of Lake Batata, an Amazonian lake. Hydrobiologia 444: 111-117, 1998.

FENNEL, K. et al. Modeling denitrification in aquatic sediments. Biogeochemistry 93: 159-178, 2009.

FERGUSON, A. J. P.; EYRE, B. D. Seasonal discrepancies in denitrification measured by isotope pairing and N2:Ar techniques. Marine Ecology Progress Series 350: 19-27, 2007.

FIGUEIREDO SOUZA, V. et al. SEDIMENT DENITRIFICATION, DNRA AND ANAMMOX RATES IN TROPICAL FLOODPLAIN LAKE (PANTANAL, BRAZIL). Oecologia Australis 16: 734-744, 2012.

GOLTERMAN, H. L.; CLYMO, R. S.; OHNSTAD, M. A. M. Methods for physical and chemical analisys of freshwater. Oxford: Blackwel Scientific Publications, 1978.

HERBERT, R. A. (1999). Nitrogen cycling in coastal marine ecosystems. FEMS Microbial Reviews 23: 281-295.

INMET. Relatório Anual do Instituto Nacional de Meteorologia. Rio de Janeiro: INMET, 1992.

JENSEN, K. et al. Estimation of Nitrification and Denitrification from Microprofiles of Oxygen and Nitrate in Model Sediment Systems. Applied and Environmental Microbiology 60: 2094-2100, 1994

KERN, J. et al. Seasonal denitrification in flooded and exposed sediments from the Amazon floodplain at Lago Camaleao. Microbial Ecology 32: 47-57, 1996 
MORLEY, N.;BAGGS, E. M. carbon and oxygen controls on N2O and N2 production during nitrate reduction. Soil Biology and Biogeochemistry 42: 1864-1871, 2010

MAROTTA, H., DUARTE, C. M., MEIRELLES-PEREIRA, F., BENTO, L., ESTEVES, F. A., ENRICH-PRAST, A. Long-Term $\mathrm{CO}_{2}$ Variability in Two Shallow Tropical Lakes Experiencing Episodic Eutrophication and Acidification Events. Ecosystems 13: 382 - 392, 2010

MORLEY, N.;BAGGS, E. M. carbon and oxygen controls on N2O and N2 production during nitrate reduction. Soil Biology and Biogeochemistry 42: 1864-1871. 2010

MOSIER, A. R.; DORAN, J. W.; FRENEY, J. R. Managing soil denitrification. Journal of Soil and Water Conservation 57: 8 - 18, 2002

NEWCOMER, T. A. et al. Influence of natural and novel organic carbon sources on denitrification in forest, degraded urban, and restored streams. Ecological Monographs, 82: 449-466, 2012

NIELSEN, L. P. Denitrification in Sediment Determined from Nitrogen Isotope Pairing. Fems Microbiology Ecology 86: 357-362, 1992

NIELSEN, L. P. et al. Denitrification and Oxygen Respiration in Biofilms Studied with a Microsensor for Nitrous-Oxide and Oxygen. Microbial Ecology 19: 63-72, 1990

NIELSEN, M. et al. Bacterium-based NO2- biosensor for environmental applications. Applied and Environmental Microbiology 70: 6551-6558, 2004

NIZZOLI, D. et al. Effect of organic enrichment and thermal regime on denitrification and dissimilatory nitrate reduction to ammonium (DNRA) in hypolimnetic sediments of two lowland lakes. Water Research 44: 2715-2724, 2010

PIEHLER, M. F.; SMYTH A. R. Habitat-specific distinctions in estuarine denitrification affect both ecosystem function and services. Ecosphere, 2:12, 2011.

PINA-OCHOA, E.; ALVAREZ-COBELAS, M. Denitrification in aquatic environments: A cross-system analysis. Biogeochemistry, 81: 111-130, 2006

RISGAARD-PETERSEN, N. Coupled nitrification-denitrification in autotrophic and heterotrophic estuarine sediments: On the influence of benthic microalgae. Limnology and Oceanography 48: 93-105, 2003

SEITZINGER, S. et al. Denitrification across landscapes and waterscapes: A synthesis. Ecological Applications 16: 2064-2090, 2006

SILVER, W. L.; HERMAN, D. J.; FIRESTONE, M. K. Dissimilatory Nitrate Reduction to Ammonium in Upland Tropical Forest Soils. Ecology 82: 2410-2416, 2001 
SMALL, G. E.; COTNER, J. B.; FINLAY, J. C.; STARK, R. A., STERNER, R. W. Nitrogen transformations at the sediment-water interface across redox gradients in the Laurentian Great Lakes. Hydrobiologia 731: 95-108. 2014

SOLOMON, C. T. et al. Sediment size and nutrients regulate denitrification in a tropical stream. Journal of the North American Benthological Society 28: 480-490, 2009

SONG, B.; LISA, J. A.; TOBIAS, C.R. Linking DNRA community structure and activity in a shallow lagoonal estuarine system. Frontiers in Microbiology 5: 1-10. 2014

SWEERTS, J. et al. Oxygen-Consuming Processes at the Profundal and Littoral Sediment Water Interface of a Small Meso-Eutrophic Lake (Lake Vechten, the Netherlands). Limnology and Oceanography 36: 1124-1133, 1991

TIEDJE, J. M. et al. DENITRIFICATION - ECOLOGICAL NICHES, COMPETITION AND SURVIVAL. Antonie Van Leeuwenhoek 48: 569-583, 1982

VIDAL, M., C.M. DUARTE, M.C. SANCHEZ. Coastal entrophication research in Europe: Progress and imbalances. Marine Pollution Bulletin 38: 851-854, 1999 
Figure captions:

Fig. 1: Map of the region. The studied lagoons are indicated by their names.

Fig. 2: Denitrification (A and B) and Dn (white bars) and Dw (shaded bars) rates; Sediment oxygen consumption (C and D) rates (SOC). Positive and negative ammonium $\left(\mathrm{NH}_{4}{ }^{+}\right)(\mathrm{E}$ and $\mathrm{F})$ and nitrate $\left(\mathrm{NO}_{3}{ }^{-}\right)$fluxes $(\mathrm{G}$ and $\mathrm{H})$ indicate respectively sediment release and consumption. For Data obtained for Imboassica (A, C, E and G) and Cabiúnas (B, D, F and H) lagoons. Symbols represent mean and SEM. Note differences in scales.

Fig. 3: Linear regression between Dn and sediment oxygen consumption (SOC) rates in Imboassica (black circle, $\mathrm{N}=47$ ) and Cabiúnas (white circle, $\mathrm{N}=31$ ) sediment. Both relationships are significant at the $5 \%$ level (F test). 
Figure 1:

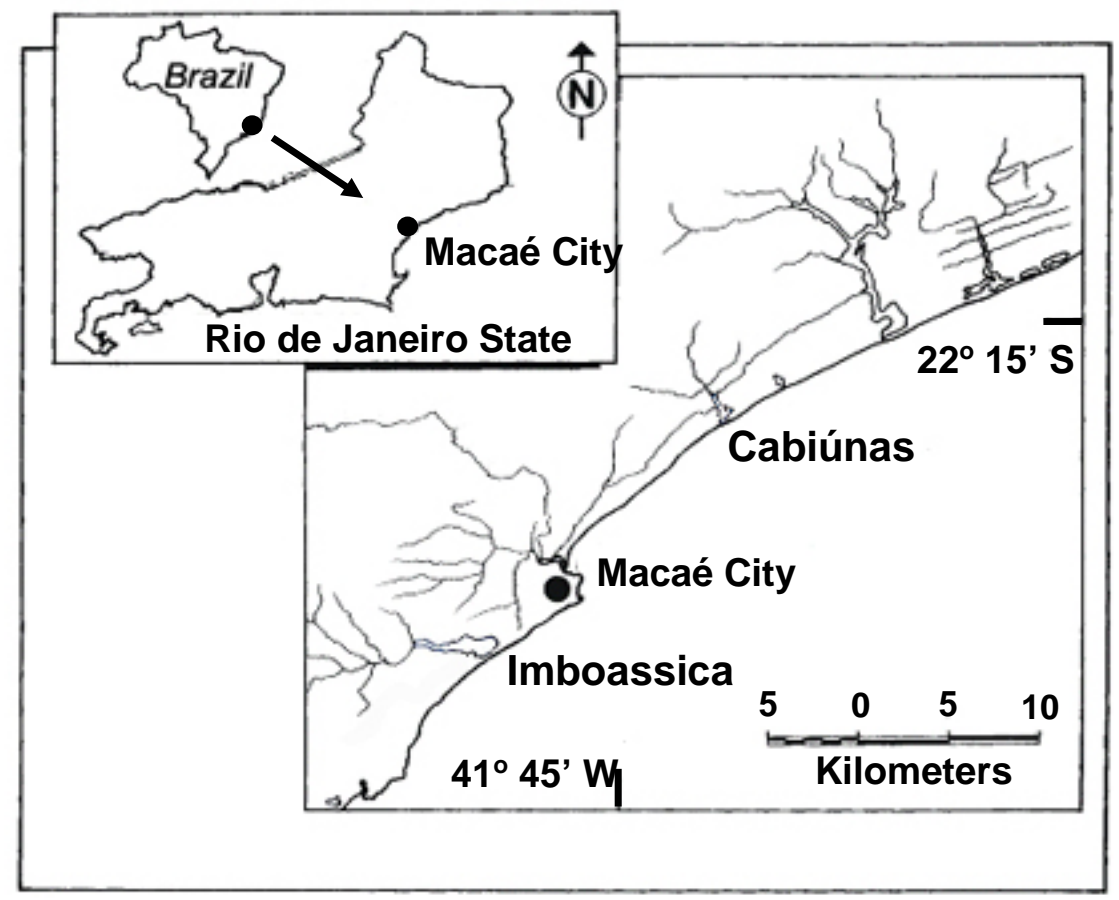


Figure 2:
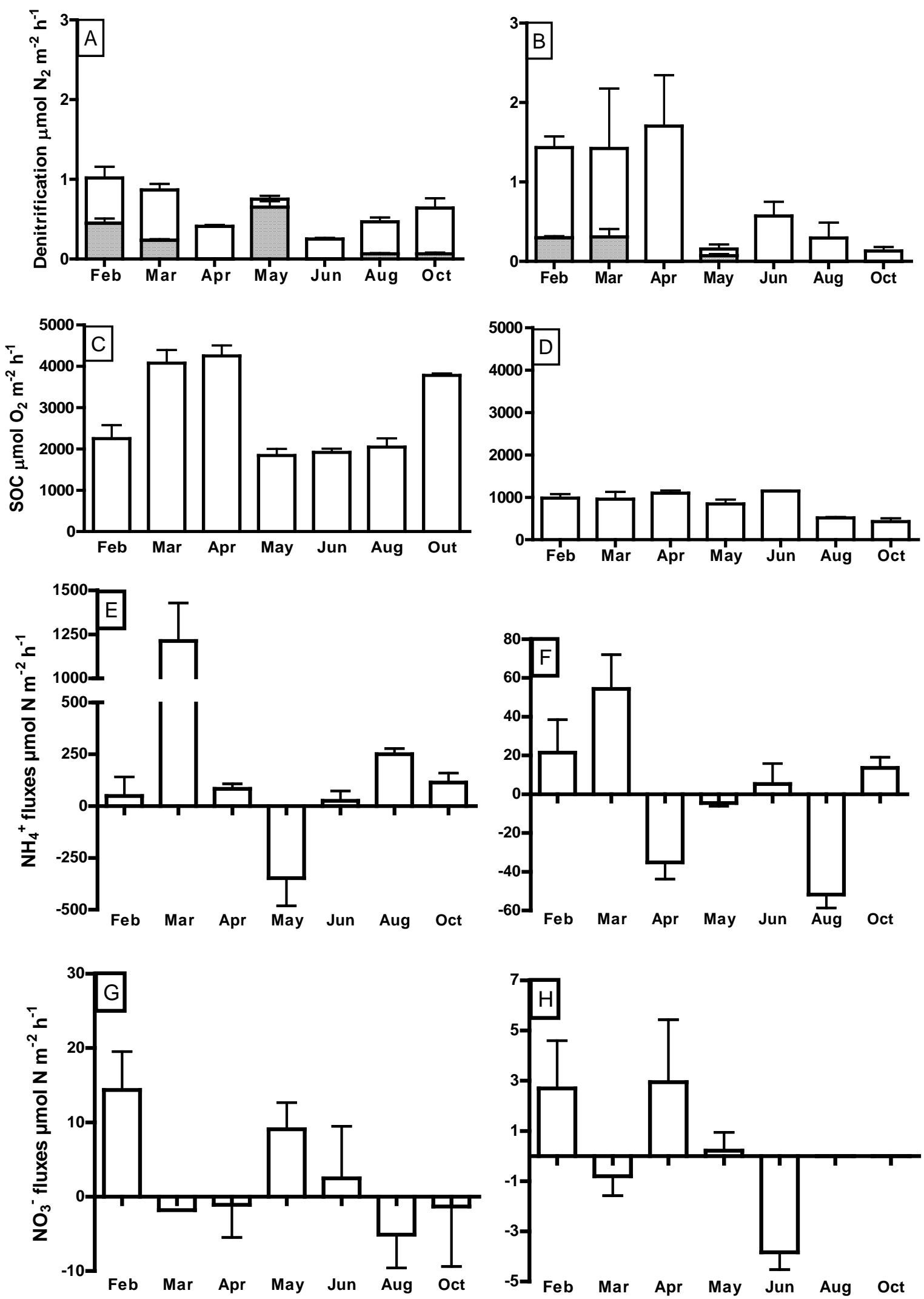
Figure 3:

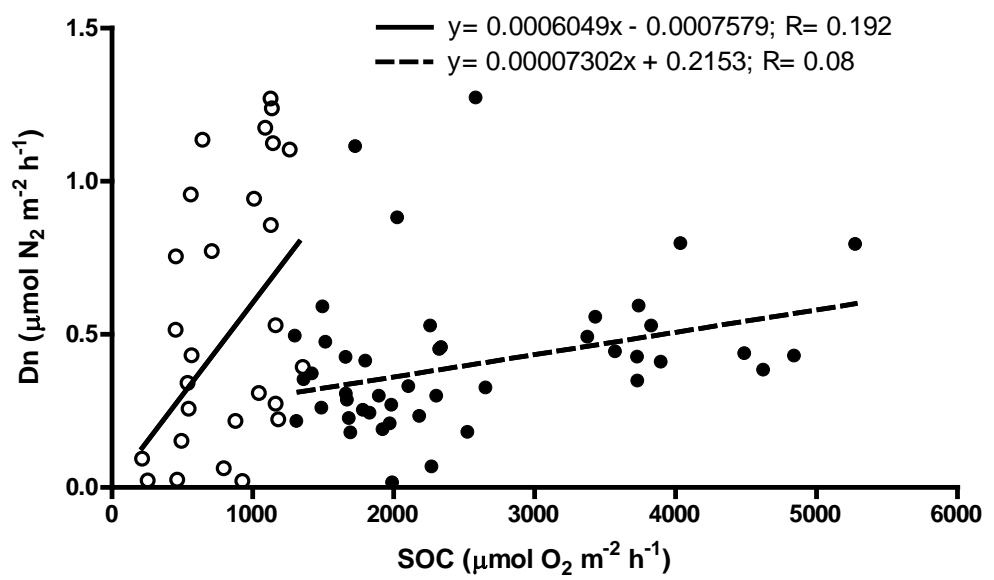


